\title{
ACHIEVING THE STATE OF RESEARCH PERTAINING TO GIS APPLICATIONS FOR CULTURAL HERITAGE BY A SYSTEMATIC LITERATURE REVIEW
}

\author{
P. Ferreira-Lopes ${ }^{1 *}$ \\ ${ }^{1}$ IUACC, HUM799, Escuela Técnica Superior de Arquitectura, Universidad de Sevilla, 41012 Seville, Spain - pwanderley@us.es
}

Commission IV, WG IV/3

KEY WORDS: Geographic Information Systems, GIS, Cultural Heritage, Systematic Literature Review, State of the art.

\begin{abstract}
:
During the last decade, we have witnessed an increased interest in Geographic Information Systems (GIS), including the so-called "Historical GIS", 3D GIS heritage and its subcategory of "SDI for cultural heritage". Specific literature reviews, gathering and analysing the scientific production for Culture Heritage and GIS based research questions, are currently lacking. Therefore, the overall goal of this article is to provide an objective summary of the current state-of-the-art concerning how GIS has been used and what methods and analysis have been applied in the field of cultural heritage. In this sense, a Systematic Literature Review (SLR) of the literature on the application of GIS in cultural heritage is carried out. To do so, the WOS and Scopus databases were considered. The results show that the dominant application of GIS is in the realisation of inventory and cataloguing of archaeological and architectural heritage. As a result of the quantitative analysis, we also verify the principal sources in which most studies have been published, highlighting the "ISPRS Archives" with 14 publications, the "Lecture Notes in Computer Science" with 9, and "Proceedings of Digital Heritage" with 6 publications. These data show that the sources that most publish mainly belong to the field of IT and Computer Science. In addition, the SLR shows that in the last three years there has been a greater tendency to use GIS to solve more specific problems of heritage through its use in conjunction with other tools such as BIM and photogrammetry.
\end{abstract}

\section{INTRODUCTION}

Information Technologies (ITs) offer a huge variety of applications in the heritage field. Geographic Information System (GIS) have been especially and increasingly more used in the last two decades, and adopted as a tool for the identification, documentation and registering, valuing, intervention and conservation, dissemination, knowledge and management of heritage. When heritage data are incorporated and treated in GIS they create a great opportunity to understand processes from a spatiotemporal and multi-scalar perspective as well as their inter-relations with other elements, whether they are physical, documentary, material or immaterial. However, the growing body of research works ends up by generating a great quantity of isolated heritage data which are unable to be inter-related with other investigations and/or disciplines, thus hindering the integral reading of the heritage and the creation of new knowledge. In particular, the application of GIS in most works of the cultural heritage area is limited to the georeferencing of information, leaving aside their enormous potential in the analysis process.

There is currently a lack of specific reviews of the literature and scientific summaries of the production concerning the use of GIS in the heritage area. The main aim of this article is therefore to contribute to the research community an objective and systematic study of the state-of-the-art concerning the use of GIS with the aim of responding to questions such as: in what heritage categories and domains is it most applied? What types of analysis are carried out? And what are the other ITs or tools which have been used in conjunction with GIS? The articles reviewed have enabled a detailed evaluation of GIS and the focuses of current research. The current systematic review also contributes a summary of the most common challenges and problems in research. Another key section of this systematic review is to identify where the results are more solid and in which fields more research is still needed. The article finishes by providing some recommendations and future research lines.

\subsection{Brief overview of GIS}

Geographic Information Systems are computational systems which enable handling information about location-linked phenomenon or characteristics. They have the functionality of a conventional database with the added particularity of the data's spatial component. This allows a space for the alphanumeric and graphic data to be explicitly dealt with. Therefore, it is a question of a computerised information system that endeavours to capture, store, manipulate, analyse and exhibit spatial data to solve complex research planning or management problems (Fischer and Nijkamp, 1992). With GIS, users can carry out innumerable analyses, such as exploring the distribution of patterns and specific characteristics, investigating interrelations, juxtaposing layers of different information, etc. The analyses done can either be only visual or consultations, parameters or more complex calculations.

The GIS phenomenon emerges during the ' 60 s simultaneously in Canada (Canada Land Inventory) and in the United States (Harvard Laboratory for Computer Graphics). In the USA GIS

* Corresponding author 
began to be applied for the automatised creation of maps, while in Canada its application was more focused on the management of water, vegetation and ground uses (Foresman, 1997). Following the line of these two initiatives, in the last decade the advances in GIS have directed their use potentially as a tool of analysis, management and visualisation of a great mass of data for decision making. Likewise, their expansion has gone from specific works initially carried out in geography and science to other disciplines such as economics, archaeology, social sciences, history, etc.

In the heritage area, GIS begins to be applied more significantly in archaeology studies during the '90s (Kvamme, 1990a, 1990b; Van Leusen, 1993, 1999; CIDOC, 1995; Fischer et al. 1997). The various initial application experiences then lead to an important publication "GIS and Cultural Resource Management", an introduction manual for the use of GIS in the management of cultural resources on both a local and national scale (BOX, 1999). From then, the use of GIS has grown considerably as the registering, compilation and treatment of the documentation and the management of the information are fundamental activities in all the phases of heritage work. Likewise, in the last years, the development of web applications has provided a broader accessibility and interaction between users and GIS, enabling a greater dissemination of their use and a reduction in costs of maintenance and investment in software.

\subsection{Previous literature reviews}

The search for literature reviews with the terms "GIS AND literature review" and "Geographic Information Systems AND literature review" was carried out in the Scopus and Web of Science (WOS) databases with a limit of the publication date and without a language restriction. Non-systematic reviews were found (Bone and Johnson, 2007; Opolot, 2013; Maina et al., 2014) and systematic reviews (Malczewski, 2006; Akkus and Ozdenerol 2014; Butler et al., 2011; Gajos and Sierka, 2012; Sharma et al., 2015). It is surprising that there are quite few reviews, only 8 , and they fundamentally deal with studies which apply GIS in disciplines such as environmental sciences, health, geography and anthropology (Table 01). This preliminary result underlines the need to carry out a review of the literature of GIS in Humanities and especially in the cultural heritage field.

\begin{tabular}{|c|c|c|c|c|c|}
\hline $\begin{array}{l}\text { Electronic } \\
\text { database }\end{array}$ & Title & Year & Source & R. Area & (SR) \\
\hline wos & $\begin{array}{l}\text { GIS-based multicriteria decision analysis: a } \\
\text { survey of the literature }\end{array}$ & & $\begin{array}{l}\text { International Journal of } \\
\text { Geographical Information } \\
\text { Science }\end{array}$ & Geography & Yes \\
\hline wos & $\begin{array}{l}\text { Identifying GIS Measures of the Physical } \\
\text { Activity Built Environment Through a Review } \\
\text { of the Literature }\end{array}$ & 2011 & $\begin{array}{l}\text { Journal of Physical Activity } \\
\text { and Health }\end{array}$ & Health & Yes \\
\hline wos & $\begin{array}{l}\text { GIS Technology in Environmental Protection: } \\
\text { Research Directions Based on Literature } \\
\text { Review }\end{array}$ & 2011 & $\begin{array}{l}\text { Polish Journal of } \\
\text { Environmental Studies }\end{array}$ & $\begin{array}{l}\text { Environmental } \\
\text { Sciences }\end{array}$ & Yes \\
\hline wos & $\begin{array}{l}\text { Exploring Childhood Lead Exposure through } \\
\text { GIS: A Review of the Recent Literature }\end{array}$ & 2014 & $\begin{array}{l}\text { Int J Environ Res Public } \\
\text { Health. }\end{array}$ & $\begin{array}{c}\text { Health and } \\
\text { Environmental } \\
\text { Sciences }\end{array}$ & Yes \\
\hline Scopus & $\begin{array}{l}\text { Human Factors in GIS Use: A Review and } \\
\text { Suggestions for Research }\end{array}$ & 2007 & $\begin{array}{l}\text { Proceedings of the Information } \\
\text { Systems Education Conference }\end{array}$ & Anthropology & No \\
\hline Scopus & $\begin{array}{l}\text { Application of Remote Sensing and } \\
\text { Geographical Information Systems in Flood } \\
\text { Management: A Review }\end{array}$ & 2013 & $\begin{array}{l}\text { Research Journal of Applied } \\
\text { Sciences, Engineering and } \\
\text { Technology }\end{array}$ & $\begin{array}{l}\text { Geology and } \\
\text { Soil Sciences }\end{array}$ & No \\
\hline Scopus & $\begin{array}{l}\text { Web geographic information system decision } \\
\text { support system for irrigation water } \\
\text { management: a review }\end{array}$ & 2014 & $\begin{array}{l}\text { Acta Agriculturae } \\
\text { Scandinavica, Section B - } \\
\text { Soil \& Plant Science }\end{array}$ & Agriculture & No \\
\hline Scopus & $\begin{array}{l}\text { Evaluation of Microalgae Biofuel Production } \\
\text { Potential and Cultivation Sites Using } \\
\text { Geographic Information Systems: A Review }\end{array}$ & 2015 & Bioenergy Research & $\begin{array}{l}\text { Agriculture } \\
\text { and } \\
\text { Environmental } \\
\text { Sciences }\end{array}$ & Yes \\
\hline
\end{tabular}

Table 1: Relation of publications which deal with the review of the GIS literature and its categorisation.
Through the study of a compendium of publications of a specific subject, the researchers can find out their state-of-theart with more ease and clarity. Likewise, a continuous examination of the literature will enable an integral view and will show the weaknesses and full potential of these areas. In this sense, this review offers the opportunity to check shortcomings, show where research has been insufficient, reveal trends and contribute to the development of knowledge in, in our case, cultural heritage.

\section{REVIEW METHOD}

This systematic literature review (SLR) was carried out in accordance with the guidelines of Gough et al. $(2013,2012)$ and divided into 10 phases: 1) Verification of the need to review the literature; 2) Definition of the questions. These will contribute to the particular structure of each review and are going to determine the key decisions, for example what type of studies to include, where to do the search, how to access them and how to bring together the findings; 3) Definition of the inclusion criteria of the publications for the sample, for example, language, location and date; 4) Choice of the bibliographical databases for the search of the publications; 5) Carrying out the screening process. This phase checks if the publications meet the inclusion criteria and the requirements to respond to the questions of phase 2 ;6) Codification and selection of the relevant information of the studies to answer the questions of phase 2 ; 7) Mapping, classification and categorisation of the information of the publications with a view to completing phases 8 and $9 ; 8$ ) Valuing of the quality and relevance of the studies; 9) Synthesising of the codified data to answer the questions; 10) Dissemination of the results.

The empirical corpus was compiled through searches in the WOS and Scopus databases with the aim of identifying the publications which specifically dealt with GIS and cultural heritage. Although these bibliometric databases are often used to carry out analyses and literature reviews, it is important to note that they have some characteristics to consider: they are predisposed to a greater quantity of publications in the area of natural sciences, engineering and biomedicine in comparison with social sciences, art and humanities; they tend to be in English; they have mainly publications in journals or proceedings - there are few monographs included. Nevertheless, both WOS and Scopus cover the publications of Elsevier, Taylor and Francis, Sage and important proceedings of congresses such as the International Archives of the Photogrammetry, Remote Sensing and Spatial Information Sciences (ISPRS Archives), in which a good part of the publications on heritage and ITs can be found.

Two search terms combination were used i) "Geographic Information Systems AND heritage" and ii) "GIS AND heritage". The searches were carried out by title, abstract and keywords in both databases. The inclusion criteria were: i) works published between 2010 and 2017; ii) works written in English, Spanish and Portuguese. The last searches were done in September 2017 and a total of 366 publications were identified, 157 in WOS and 209 in Scopus.

After defining the inclusion criteria and carrying out the compilation, a generic analysis was done of the material to define the questions which we sought to answer (Table 02). In an SLR the questions are a key part of the methodology as 
these will guide the screening phases, mapping, valuing and synthesis. As the review's aim is to determine what type of application GIS has had in the area of cultural heritage, the following questions were defined:

Q1. What has the study aim's object/heritage category been? 3 categories were considered: Immovable Heritage (subcategories: archaeology, architectural and landscape), movable heritage (subcategories: documents, objects, etc.) and intangible heritage. Some publications cover more than one category.

Q2. What domains are the GIS applied to? These have been grouped into 5 domains: Inventory and Cataloguing; Analysis and Research; Development of management and protection plans; Prediction and evaluation of impacts; Dissemination (Box, 2009).

\section{Q3. What analyses were done?}

\section{Q4. What other digital technologies were used?}

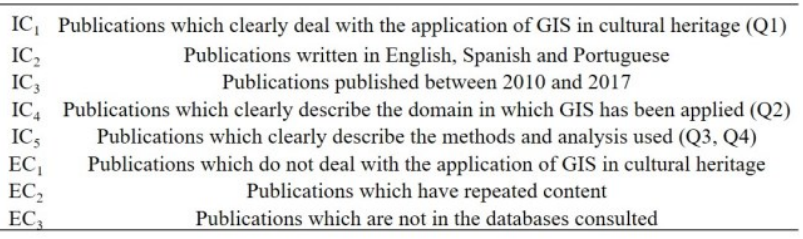

Table 02: Definition of the Inclusion (IC) and exclusion criteria (EC) for the qualitative review.

The details of the flow of the review process can be observed in the diagram of Figure 1 and are part of the external technical report. A total of 366 publications were found, of which 35 were in both databases, so the duplicates were excluded. A total of 198 remained in the sample after the first screening, which was done via analysing the title and the abstract of the publications compiled. Of these, 25 could not be accessed to read the complete text (they were not included in the subscriptions of the University of Seville and the Vrije Universiteit Amsterdam or were not open-access), so they were excluded from the sample. During the $2^{\text {nd. }}$ screening process, in which we completely read the 173 publications, 65 were excluded. The sample for the quantitative and qualitative analyses had a total of 108 publications. The details of the flow of the review process can be observed in the diagram in Figure 1 and are part of the external technical report (Figure 1 and Table 03).

To carry out the review process a database was designed with a structure of calculation sheets in the .xls format in which each publication contains a series of attributes related with the basic information of the publications (author, date, source published, abstract, keywords, DOI, number citations) and with the questions. This was in order to facilitate the codification process. For all of the articles that were not false positives, a set of codes was developed to draw classification patterns and answer the questions. Therefore, true-false type codes are used ( 1 or 0 ) and those of words or short phrases which correspond to the classification established by the questions. As a support for the Valuation and Synthesis phases a field for observations was also incorporated.

\begin{tabular}{cccccc}
\hline $\begin{array}{c}\text { Electronic } \\
\text { database }\end{array}$ & $\begin{array}{c}\text { Search (1) and } \\
\text { (2) - Extract }\end{array}$ & $\begin{array}{c}\text { Duplicated } \\
\text { records }\end{array}$ & 10 screening & $\begin{array}{c}\text { without access } \\
\text { (papers excluded) }\end{array}$ & 20 screening \\
\hline WOS & 157 & & 73 & 4 & 44 \\
\hline Scopus & 209 & 35 & 125 & 21 & 64 \\
\hline total & 366 & 35 & 198 & 25 & 108 \\
\hline
\end{tabular}

Table 3: Papers included and excluded during the Systematic review.

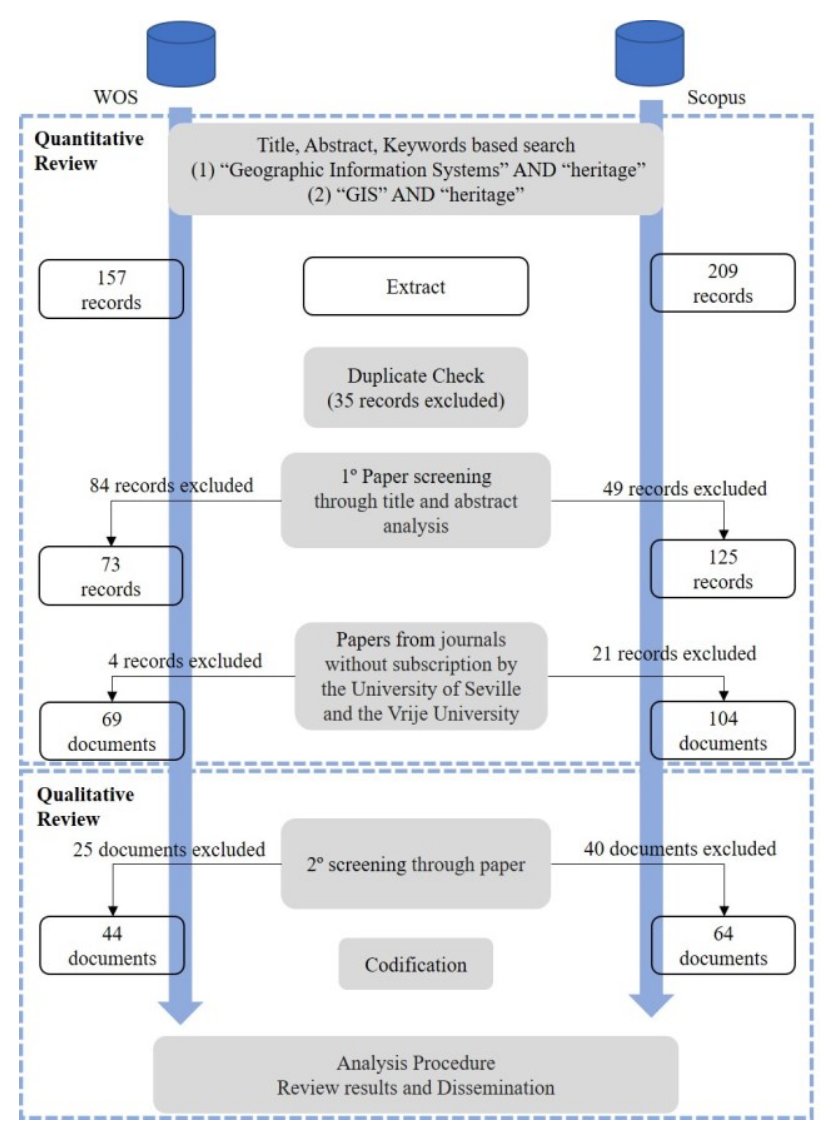

Figure 1: Flow diagram of the SLR methodology, number of publications included and excluded in each phase.

\section{REVIEW RESULTS}

Analysing the years of all the publications, a greater number is noted in 2015. Between the years 2014 and 2017 their number increases almost $45 \%$ when compared with the period 2010 to 2013, going from 147 to 219 . The growth trend is repeated when we analyse the publications included in the review, going from 43 to 66 (Figure 2). As a result of a quantitative analysis, we can also check the sources in which most articles been published. The sources that stand out are "ISPRS Archives" with 14 publications, "Lecture Notes in Computer Science" with 9 and "Proceedings of the Digital Heritage" with 6 (Table 04). These data demonstrate that the sources which most publish mainly belong to the area of ITs and Computer Science. 


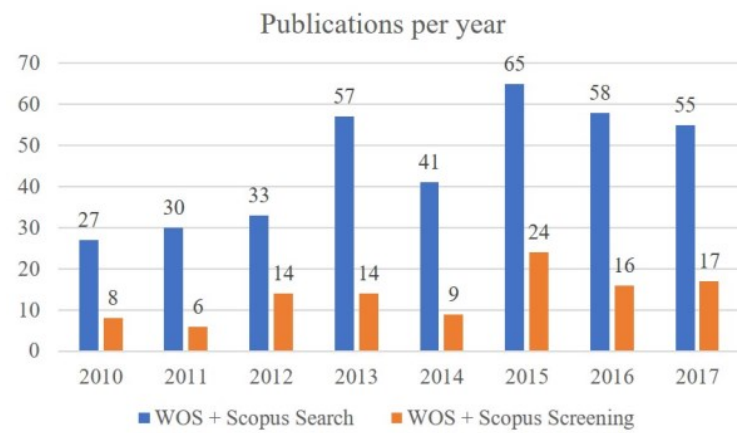

Figure 2: Graph showing comparison of the number of publications per year.

\begin{tabular}{clc}
\hline Ranking & \multicolumn{1}{c}{ Source } & \multicolumn{1}{c}{$\begin{array}{c}\mathrm{n}^{\circ} \text { papers } \\
\text { included (SR) }\end{array}$} \\
\hline 1 & $\begin{array}{l}\text { International Archives of the Photogrammetry, Remote } \\
\text { Sensing and Spatial Information Sciences - ISPRS Archives }\end{array}$ & 14 \\
2 & $\begin{array}{l}\text { Lecture Notes in Computer Science (including subseries } \\
\text { Lecture Notes in Artificial Intelligence and Lecture Notes in } \\
\text { Bioinformatics) }\end{array}$ & 9 \\
& $\begin{array}{l}\text { Proceedings of the Digital Heritage 2013 - Federating the } \\
\text { 19th Int'l VSMM, 10th Eurographics GCH, and 2nd UNESCO }\end{array}$ & 6 \\
& $\begin{array}{l}\text { Memory of the World Conferences, Plus Special Sessions } \\
\text { from CAA, Arqueologica 2.0 et al. }\end{array}$ & 4 \\
4 & Journal of Archaeological Science & 3 \\
5 & 25th International CIPA Symposium 2015 & 3 \\
6 & Science of the Total Environment
\end{tabular}

Table 04: List of sources of publications with more than three articles.

In the next sections we will answer the research questions.

\subsection{Q1: What heritage object/category has been the study aim?}

The study aims were analysed and categorised to discover in which heritage category (Immovable, Movable, Immaterial) the GIS tool has been most applied. $93 \%$ of the publications have immovable heritage as their study aim, only $6 \%$ correspond to publications which apply GIS in research into movable heritage and hardly $1 \%$, immaterial heritage. In just one case the study of immovable and movable heritage occurs (Soler, Melero, and Luzon, 2017). As to the categorisation of the heritage object, $53 \%$ of the publications apply GIS in architectural heritage, $30 \%$ in archaeological, $10 \%$ in landscape and $1 \%$ in immaterial heritage (Figure 3).
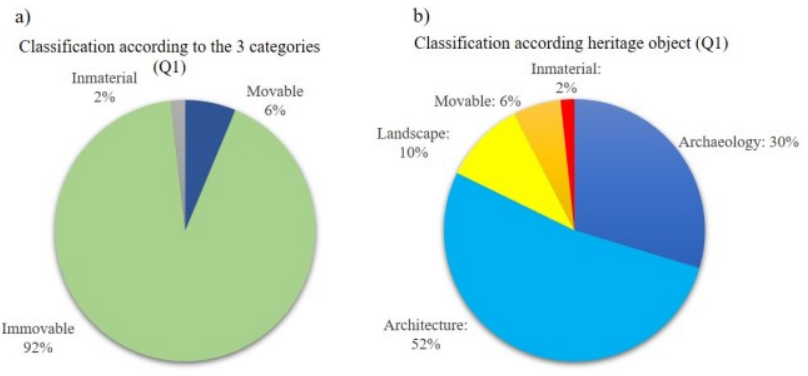

Figure 3: Quantitative graph of the representation of the different categories and classifications (Q1).

\subsection{Q2: In which domains does the application of GIS predominate?}

The application domains were analysed via the inclusion of the codification in the tables of the.$x \mathrm{ml}$ list. In each publication and for each domain a value " 0 " or " 1 " has been introduced, negative or positive, respectively. The same publication can obtain two or more positive domains. All those publications which have created a spatial database for heritage registering and identification are classified as positive in the domain Inventory and Cataloguing. For the domain "Analysis and Research" those publications were classified as positive which have developed analysis through GIS for heritage knowledge, such as: density, heat maps, viewsheds, comparison and juxtaposition of layers and data, queries, influence area, stratigraphic analysis, subject maps, time analysis, etc. Those which have elaborated a monitoring, control and management system of a heritage object or centre are in the Development of protection and management plans domain. In the Prediction and evaluation of impacts domain are those which try to detect or predict risks caused by phenomena which endanger the preservation of the heritage, such as: floods, earthquakes, fires, pollution, and anthropic actions, among others. And lastly, those publications which focus on actions of transmission of heritage knowledge are in the Dissemination domain.

$68,5 \%$ of the publications have used GIS to carry out an inventory and cataloguing, 66,7\% for Analysis and research, $28,7 \%$ for heritage dissemination, $23,1 \%$ for the development of protection and management plans and $18,5 \%$ for the prediction and evaluation of impacts (Figure 4). In this sense, we can verify that the application of the tool has been centred significantly in works of heritage inventory, analysis and research which, in a certain manner, correspond to the first phases of the "heritage chain" (Azkarate et al., 2009) as an integral management model: identification, documentation, registering and signification.

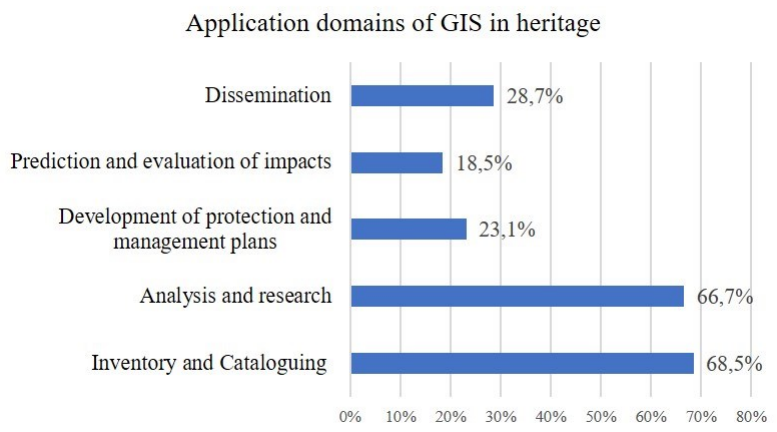

Figure 4: Graph of the application domains of GIS in heritage.

\subsection{Q3: What were the analyses carried out?}

The analyses carried out with GIS heavily depend on the heritage category and on the domain in which the works have been developed. The aim of the codification is to obtain greater detail about the types of analysis done. 14 types were codified, the same study being able to present more than one type of analysis: 1) Alphanumeric analysis and/or queries, SQL Analysis; 2) Subject maps; 3) Time analysis; 4) Visualisation in 3D; 5) Geometric analysis; 6) Juxtaposition in layers; 7) Density analysis; 8) Pathology; 9) Visibility analysis (visual 
connectivity); 10) Multicriteria analysis; 11) Image processing; 12) Accessibility; 13) Stratigraphic; 14) Sun/shade orientation (Figure 5). The most frequent analyses are those that are alphanumeric (50 publications) and subject maps (58 publications). The publications analyse the heritage information via attributes, consulting and/or filtering and generating, from this, subject maps which will be used for the visualisation of the analysis. Of the 108 articles only 20 carry out 3D visualisations. This data can be explained by both the development of the GIS tool itself in the last years and by a greater accessibility to techniques such as photogrammetry and scanning.

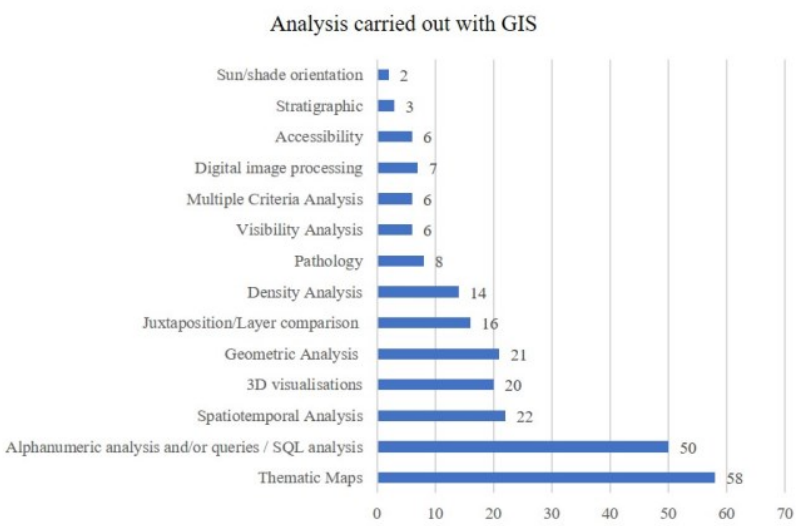

Figure 5: Types of analysis in GIS which have been done in the studies.

Likewise, the results of the codification of the analyses carried out indicate a trend in recent years of the use of GIS to solve more specific heritage problems, such as the analysis of pathology (8 publications) and stratigraphic analysis (3 publications). As to the analysis of pathology, three methodologies or procedures are observed: 1) via the table of attributes which is associated with the geometric entity (Lazzari et al., 2014); 2) through the association of a scale of the pathological level with the elements of parts of the building defined in the table of attributes (Chatzigrigoriou, 2016); and 3 ) the quantitative analysis of deterioration in the element (André et al., 2014).

When the interest of the study lies in the analysis of visual connectivity, the viewshed and observer points have been analysed to help in urban planning decision making (Cassatella and Carlone, 2013), or to understand the system of visual connection of a specific object or heritage centre (De Montis and Caschili, 2012; Salvador and Vitti, 2011).

With relation to image processing ( 7 publications) three applicabilities are noted: for systematisation, the creation of new information and generation of hypotheses or prediction, such as in Lamenza (Lamenza, 2015), which uses images of Landasat, of GoogleEarth and of the DEM model; to visualise the evolution from historic air images; and to identify new elements from algorithms, such as in Abrate (Abrate et al., 2013).

\subsection{Q4: Which other Digital Technologies were used?}

We have analysed three other technologies or tools used in conjunction with GIS: Photogrammetry, Laser/Scanner, and BIM (Fig. 6). Eighteen of the publications reviewed have used
Laser Scanner, the majority being applied in archaeology. The great usefulness and the potential of the use of scanning, especially the utilisation of LIDAR, lies in the registering and prediction of new archaeological sites (Stein et al., 2017; Smith et al., 2013). In other cases, it is used to get a greater precision of the DTM, as in Paolini et al. (2013) or for virtual reconstruction, as in Berthelot et al. (2015) (Figure 6).

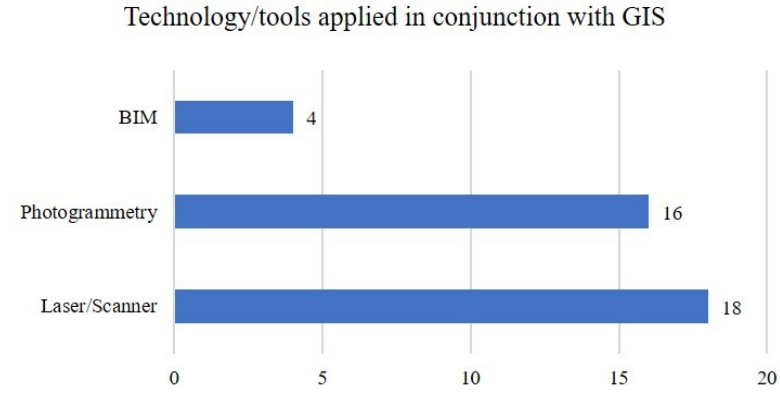

Figure 6: Quantitative analysis of the technologies/tools which were applied in conjunction with GIS in the publications included in the systematic review.

\section{CONCLUSIONS}

This article has presented a systematic literature review of the literature on the state-of-the-art concerning GIS applications in the heritage area. The systematic review method proposed considers and combines the results of searches in two heterogenous digital databases and enables an evaluation which can be applied to other studies and analysis. Via the implementation of a search based on equations of keywords and taking into account the results of the analysis of the metadata of the publications, it is possible to minimise the risk of bias during the process of the literature review. We have answered the initial research questions and provide new statistics and analysis of the state- of-the-art of GIS in heritage.

During the SLR process an increase of publications from 2014 has been noted. This data reflects the growth of the development and interest in ITs, and the rise of multidisciplinary investigations. Nonetheless, most studies are limited to processing the alphanumeric information linked to the heritage entity for the generation of subject maps. Thus, the use of GIS for carrying out inventories and cataloguing predominates Some reasons for this limitation could be a lack of training and professional updating, questions which have already been tackled in the field of humanities (Ayers, 2010). There is a noticeable need for new research which dominates the GIS tool to capitalise on its potential of analysis focused on the knowledge and management of heritage information.

Also, the paucity of studies which consider the maintenance and sustainability of information has been observed. In some cases, new platforms have been created to diffuse and facilitate the accessibility of the information generated in the investigation. However, over time they have ceased to work, due to a lack of either the project's continuity or of financing. In this sense, there still exists a huge gap to be studied and a void regarding the strategy of sustainability and accessibility of data. Where do all the data generated in the research remain? Has some policy or protocol been applied for its use, re-use and enhancement in the future? These and other questions have not 
been contemplated in any of the publications analysed and may perfectly well be a future research line: the maintenance and sustainability of heritage data.

\section{ACKNOWLEDGEMENTS}

This article has been carried out in the framework of the R\&D\&i Projects HAR2016-78113-R and HAR2016-76371-P funded by the government of Spain's Ministry of Economy and Competitiveness. Moreover, I wish to thank all the researchers and professionals who have been contacted to clarify data or methodologies during the process of the systematic review.

\section{REFERENCES}

Abrate, M., Bacciu, C., Hast, A., Marchetti, A., Minutoli, S., Tesconi, M. 2013. GeoMemories-A Platform for Visualizing Historical, Environmental and Geospatial Changes in the Italian Landscape. Int. J. Geo-Inf., 2(2), pp. 432-455, doi:10.3390/ijgi2020432.

Akkus, C., Ozdenerol, E. 2014. Exploring Childhood Lead Exposure through GIS: A Review of the Recent Literature. Int J Environ Res Public Health, 11(6), pp. 6314-6334, doi.org/10.3390/ijerph110606314.

André, M-F., Vautier F., Voldoire, O., Roussel, E. 2014. Accelerated stone deterioration induced by forest clearance around the Angkor temples. Science of the Total Environment, 493(15), pp. 98-108, doi.org/10.1016/j.scitotenv.2014.05.141.

Azkarate, A., Barreiro, D., Criado, F., García Camino, I., Gutiérrez Lloret, S., Quirós, J.A., Salvatierra, V. 2009. La Arqueología hoy. In: Actas Congreso: Medio siglo de arqueología en el cantábrico oriental y su entorno. VitoriaGasteiz, pp. 599-615.

Ayers, L. E. 2010. Turning toward Place, Space and Time. In: The spatial humanities: GIS and the future of humanities scholarship, Indiana University Press, pp. 1-13.

Berthelot, M., Nony, N., Gugi, L., Bishop, A., De Luca, L. 2015. The Avignon bridge: a 3D reconstruction project integrating archaeological, historical and gemorphological issues. In: Int. Arch. Photogramm. Remote Sens. Spatial Inf. Sci, Vol. XL 5/W4 (5), pp. 223-227, doi.org/10.5194/isprsarchives-XL-5-W4-223-2015

Bone, T., Johnson, D. 2007. Human Factors in GIS Use: A Review and Suggestions for Research. In: Proceedings of the Information Systems Education Conference - ISECON, 24, pp. $1-15$.

Box, P. 1999. GIS and Cultural Resource Management: A manual for Heritage Managers. UNESCO, Bangkok.

Butler, E. N., Ambs, A.M., Reedy, J., Bowles H.R. 2011. Identifying GIS measures of the physical activity-built environment through a review of the literature. J Phys Act Health 1(S9), pp. 1-7.

Cassatella C., Carlone G. 2013. GIS-based visual analysis for planning and designing historic urban landscapes: The case of
Turin. In: Digital Heritage International Congress, Vol. 1, pp. 45-52, doi.org/10.1109/DigitalHeritage.2013.6744728.

Chatzigrigoriou P. 2016. Taking the next step in digital documentation of historic cities: How HERMeS evolved in an open data digital library of historic buildings. Lecture Notes in Computer Science LNCS, 10058, pp. 144-156, doi.org/10.1007/978-3-319-48496-9_12

CIDOC. 1995. Draft International Core Data Standard for Archaeological Sites and Monuments. International Documentation Committee, International Council of Museums.

De Montis, A., Caschili, S. 2012. Nuraghes and landscape planning: Coupling viewshed with complex network analysis. Landscape and Urban Planning, 105(3), pp. 315-324, doi.org/10.1016/j.landurbplan.2012.01.005.

Fischer, M. M., Nijkamp, P. 1992. Geographic information System and spatial analysis. The Annals of Regional Science 26 (1), pp. 3-17, doi.org/ 10.1007/BF01581477

Fischer, P. F., Farrelly, C., Maddocks, A., Ruggles, C. L. N. 1997. Spatial analysis of visible areas from the Bronze Age cairns of Mull. Journal of Archaeological Science, 24, pp. 581-592, doi.org/ 10.1006/jasc.1996.0142.

Foresman, T. W., Ed. 1997. The History of Geographic Information Systems: Perspectives from the Pioneers. Prentice Hall PTR Upper Saddle River, New Jersey.

Gajos, M., Sierka, E. 2012. GIS Technology in Environmental Protection: Research Directions Based on Literature Review. Polish Journal of Environmental Studies 21 (2), pp. 241-248.

Gough, D., Oliver, S., Thomas, J. 2012. An Introduction to Systematic Reviews. SAGE Publications, London.

Gough, D., Oliver, S., Thomas, J. 2013. Learning from research: Systematic reviews for informing policy decisions: A quick guide. Nesta, London.

Kvamme, K. L. 1990a. GIS algorithms and their effects on regional archaeological analyses. In: Interpreting Space: GIS and Archaeology, Taylor \& Francis, pp. 112-125.

Kvamme, K. L. 1990b. One-sample tests in regional archaeological analysis: new possibilities through computer technology. American Antiquity, 55, pp. 367-381, doi.org/10.2307/281655.

Lamenza, G.N. 2015. SIG y teledetectacción en investigaciones del Chaco argentino. Arqueología Iberoamericana, 27, pp. 4054.

Lazzari M., Patriziano M.S., Aliano G.A. 2014. GIS assessment and planning of conservation priorities of historical centers through quantitative methods of vulnerability analysis: An example from southern Italy. Lecture Notes in Computer Science LNCS, 8580 (2), pp. 677-692, doi.org/10.1007/978-3319-09129-7_49 
Maina, M.M., Amin, M.S.M., Yazid, M.A. 2014. Web geographic information system decision support system for irrigation water management: a review. Acta Agriculturae Scandinavica, Section B - Soil \& Plant Science, 64(4), pp. 283293, doi.org/10.1080/09064710.2014.896935

Malczewski, J. 2006. GIS-based multicriteria decision analysis: a survey of the literature. International Journal of Geographical Information Science, 20 (7), pp. 703-726, doi.org/10.1080/13658810600661508

Opolot, E. 2013. Application of Remote Sensing and Geographical Information Systems in Flood Management: A Review. Research Journal of Applied Sciences, Engineering and Technology, 6(10), pp. 1884-1894, doi.org/10.1023/B:NHAZ.0000037035.65105.95.

Paolini P., Allegrini Simonetti F., Forti G., Corrao A. 2013. Ancient Rome worldwide links: Sharing knowledge to preserve the roots. In: Int. Arch. Photogramm. Remote Sens. Spatial Inf. Sci, XL5/W2, pp. 465-470, doi.org/10.5194/isprsarchives-XL5-W2-465-2013

Salvador I., Vitti A. 2011. Survey, representation and analysis of a world war I complex system of surface and underground fortifications in the Gresta Valley - Italy. In: Int. Arch. Photogramm. Remote Sens. Spatial Inf. Sci, XXXVIII-5W16, pp. 319-325, doi.org/10.5194/isprsarchives-XXXVIII-5-W16319-2011.

Sharma, B., Brandes, E., Khanchi, A., Birrell, S., Heaton, E., Miguez, F. E. 2015. Evaluation of Microalgae Biofuel Production Potential and Cultivation Sites Using Geographic Information Systems: A Review. Bioenergy Research, 8(4), pp. 1714-1734, doi.org/10.1007/s12155-015-9623-0.

Smith N.G., Knabb K., Defanti C., Weber P., Schulze J., Prudhomme A., Kuester F., Levy T.E., Defanti T.A. 2014. ArtifactVis2: Managing real-time archaeological data in immersive 3D environments. In: Digital Heritage International Congress, 1, pp.363-370, doi.org/10.1109/DigitalHeritage.2013.6743761.

Soler, F., Melero, F.J., Luzon, M.V. 2017. A complete 3D information system for cultural heritage documentation. Journal of Cultural Heritage, 23, pp. 49-57, doi.org/10.1016/j.culher.2016.09.008.

Stein S., Malone S., Knight D., J. Howard A., Carey C. 2017. New Approaches to Mapping and Managing Paleochannel Resources in the Light of Future Environmental Change: A Case Study from the Trent Valley, UK. The Historic Environment: Policy and Practice, 8(2), pp.113-124, doi.org/10.1080/17567505.2017.1317086.

Van Leusen, P. M. 1993. Cartographic modelling in a cellbased GIS. In: Computing the Past: Computer Applications and Quantitative Methods in Archaeology. Aarhus University Press, Aarhus, pp. 105-123.

Van Leusen, P. M. 1999. Viewshed and Cost Surface Analysis Using GIS (Cartographic Modelling in a Cell-Based GIS II). In: New Techniques for Old Times: Computer Applications and
Quantitative Methods in Archaeology, Aarhus University Press, Aarhus, pp. 215-224. 